\title{
Four Corners: an educational strategy for learning infectious diseases in medical school
}

Four Corners: uma estratégia educacional para o ensino de infectologia para estudantes de Medicina

\author{
Bárbara Labella Henriques' (1) | labella.bh@gmail.com \\ Maria Claudia Stockler Almeida' (1) maria.stockler@hc.fm.usp.br \\ Ronaldo Cesar Borges Gryschek' 10 rcbgry@usp.br \\ Vivian Avelino-Silva' (1) viviansilva87@gmail.com
}

\begin{abstract}
Introduction: An extensive literature has demonstrated the benefits of active learning in medical education and has revealed the need for updating the teaching methodologies. Active learning strategies consolidate the theoretical knowledge, while simultaneously encouraging the student's concrete abilities. Nonetheless, remodeling the pedagogical practice is challenging. Several active learning strategies are available and selecting the most suitable one is often a matter of format, not of content. In this article, we discuss the experience of the'Four Corners' technique in the teaching of Infectious Diseases during the internship at our institution.
\end{abstract}

Experience report: The four corners strategy can be adapted to different topics and should be implemented as follows: 1. pre-activity learning: students receive the supportive material for previous analysis; 2. Preparation of the room: each of the four corners is labeled with a different case vignette; 3 . Dividing tasks: the specific assignments are divided among the students; 4 . Activity: the students read the case vignette and discuss the questions, while the mediator has an observer's role, and 5. Debriefing: final discussion with all participants led by the mediator. The entire process takes from $2 \mathrm{~h} 30$ to 3 hours.

Discussion: The educational process emerges from the learner's experience. Many instructors working in higher education believe they promote critical thinking and active teaching during their classes; however, the percentage of teachers who regularly use active teaching strategies is still low. A range of different active learning strategies have been described and many can be adapted to different scenarios; most approaches change the nature of the learning experience but do not always require a change in the given subject. The Four Corners technique is an active learning strategy that promotes debate and exchange of ideas among students.

Conclusion: This experience report describes an active learning strategy for the teaching of Infectious Diseases to medical students. The medical education improvement goes through highlighting the teacher's role as a mediator of the learning process; proposing new teaching strategies is challenging and requires frequent adjustments. The Four Corners strategy improves student's engagement with the learning process, and it is an efficient strategy to comprise an extensive theoretical content in a relatively short discussion time.

Keywords: Medical Education; Problem-Based Learning; Communicable Diseases.

\section{RESUMO}

Introdução: Uma extensa literatura demonstra os benefícios do ensino ativo na educação médica e a necessidade de atualização das metodologias de ensino. As estratégias de aprendizagem ativa consolidam o conhecimento teórico e estimulam as habilidades conceituais do aluno. No entanto, reformar a prática pedagógica é desafiador. Existem diversas estratégias de aprendizagem ativa que sugerem uma adaptação do formato de entrega do conteúdo, de modo a adequá-las a diversos contextos. Neste artigo, discutimos a experiência da aplicação da técnica Four Corners no ensino de doenças infecciosas em nossa instituição.

Relato de experiência: A estratégia Four Corners foi implementada da seguinte maneira: 1. preparação: os estudantes recebem material de estudo para análise prévia; 2. preparação da sala: cada um dos quatro cantos recebe cartelas com os casos clínicos escolhidos; 3. divisão de tarefas: as tarefas são divididas entre os estudantes; 4. atividade: os estudantes leem e discutem cada um dos casos propostos com mínima interferência do moderador; 5. finalização: discussão final com todos os participantes liderados pelo moderador. A duração de toda a tarefa varia de duas horas e meia a três horas.

Discussão: O processo educacional emerge da experiência do aprendiz. Muitos professores do ensino superior acreditam que promovem o pensamento crítico por meio do ensino ativo em suas aulas, entretanto a porcentagem dos que aplicam essas técnicas ainda é baixa. Existe uma ampla variedade de técnicas ativas de ensino, e muitas delas se adaptam a diferentes cenários. A técnica Four Corners é uma estratégia de aprendizagem ativa que promove debate e troca de conceitos entre os estudantes.

Conclusão: Este relato de experiência descreve uma estratégia de aprendizagem ativa para o ensino de doenças infecciosas para estudantes de Medicina. O aprimoramento da educação médica passa por entender o papel do professor como mediador do processo de aprendizagem. Propor novas estratégias de ensino é desafiador e requer ajustes frequentes. A estratégia Four Corners melhora o envolvimento do aluno com o processo de aprendizagem e é eficiente para compreender um conteúdo teórico extenso em um tempo de discussão relativamente curto.

Palavras-chave: Educação Médica; Aprendizagem baseada em problemas; Doenças Transmissíveis.

1 Universidade de São Paulo, São Paulo, São Paulo, Brazil.

Chief Editor: Rosiane Viana Zuza Diniz.

| Associate Editor: Pedro Tadao Hamamoto Filho.

Received on 01/13/21; Accepted on 05/10/21. | Evaluated by double blind review process. 


\section{INTRODUCTION}

In the last decades, several authors have demonstrated the advantages of using active learning techniques in medical education'. Active methods allow a deeper and more permanent understanding of the learning content, improving the quality of healthcare professionals ${ }^{2,3}$.

Traditional models are excessively focused on the theoretical content and on the teacher as the 'owner' of the knowledge; students are often seen as passive learners. A hierarchy is defined between the teacher and the student. Traditional teaching models are based on memorization, repetition and verification of assimilation. However, relying solely on the accumulation of new information during the learning process is not enough for the exponential expansion of medical knowledge seen in the last century. It is estimated that if medical training depended only on the transfer of theoretical content, the time required to cover all available knowledge would be approximately 40 years, not to mention new advances that could happen during that period ${ }^{4}$.

Medical schools have an essential role not only in structuring nuclear technical knowledge but also in promoting a favorable environment so that students can develop autonomy in learning ${ }^{5}$. Medical training is not finalized by the end of undergraduate school, and after graduation medical doctors must remain engaged in learning new information applied in every practice.

From 2011 to 2014 the University of Sao Paulo Medical School underwent an extensive curricular restructuring of the medical undergraduate program through the adoption of a competency-based curriculum ${ }^{6}$. In 2014, University of Sao Paulo Medical School assembly approved a new curriculum, which was first applied to the first-year students in 2015; therefore, the first internship class under the new curriculum started the 2019. The new competency-based curriculum relies on the basic-clinical program organized in modules aiming to promote the integration of subjects between departments. The new proposal expands the knowledge obtained by the student and includes a $30 \%$ reduction in classroom hours compared to the previous curriculum, currently comprising about 7,500 hours. This change allows complementary activities, including scientific activities, academic leagues, sports, and others ${ }^{4}$.

This restructuring led to an adjustment of the theoretical and practical basics of the Infectious Diseases program in the third and fourth years of medical school. Additionally, the fifth year of our program, which corresponds to the internship in Infectious Diseases, was shortened from a 28-day ward-based training for groups of 14-16 students to a 7-day training with most activities focused on the outpatient clinic training for groups of 4-6 students.
Therefore, mostly due to a decrease in the workload dedicated to the infectious disease program in the internship and prioritizing active learning techniques, an extensive change in the Infectious Diseases undergraduate program was necessary. Looking forward to this change, we adopted a version of the Four Corners teaching technique ${ }^{5,6}$ for promoting active discussion of clinical cases in our program, aiming to stimulate student's abilities of listening, verbal communication and critical thinking in decision-making. The Four Corners is a cooperative teaching technique that requires students to express their opinions on a specific question or problem through a discussion with their peers, thus improving their communication skills, promoting the development of critical thinking and the capacity to identify solutions in different topics. In this manuscript, we describe how this technique was adapted and applied to University of Sao Paulo Medical School's $5^{\text {th }}$ year of the medical school internship program in 2019.

\section{EXPERIENCE REPORT}

In 2019, Internal Medicine and Infectious Diseases of the $5^{\text {th }}$ year of University of Sao Paulo Medical School had an Integrated internship program that lasted seven weeks, of which seven days comprised the Infectious Diseases internship program. Every week, 4 to 6 students attended a 4-hour activity, which was adapted from the Four Corners technique. In the year of 2019, 150 students attended the activity.

The Four Corners strategy requires that participants declare their opinions on a specific statement or question. In the traditional model, the teacher prepares the classroom before the activity and labels each corner with a different option (strongly agree, agree, disagree, strongly disagree). During the activity, the teacher presents a problem or question, and each student takes a position according to their opinion (Figure 1).

The traditional model is suitable for closed-ended questions and performs well in a warm-up before a presentation. A possible adaptation is to label each corner with a different case vignette with three or four questions, addressing the topics to

Figure 1. An example of one student's position in the classroom after the presentation of a question while using the Four Corners strategy.

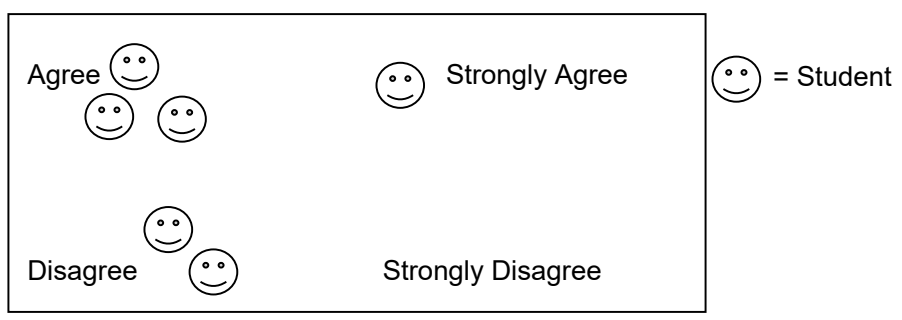


be discussed. The teacher divides the students into groups of 3 to 5 people and each of them begins in one corner, rotating positions as the activity progresses (Figure 2 ). Our proposal while performing this activity was to discuss case vignettes without closed answers, exploring the multiple possibilities with the students and, therefore, the last model, detailed below, was chosen for our activity.

\section{Topic selection}

The topic for the activity was defined based on the infectious disease curriculum for $5^{\text {th }}$ year medical students. The aim was to cover several topics in a short period of time, selecting those already presented as traditional lectures but reshaped as clinical case scenarios. Table 1 shows details of the topics covered throughout the year and the questions addressed in each station. The activity was conducted according to the following:

1. Pre-activity learning: one week before the interactive session, students received in a web platform video classes, epidemiological reports, review manuscripts and guidelines related to the eight topics described in Table 1. The material was selected by the teacher, with a focus on the learning objectives and also targeting the level of our audience;

2. Room arrangement: Each of the four corners of the classroom was labeled with a different case vignette printed on cardboard, based on the topics to be addressed;

3. Dividing tasks: The assignments to be divided among the students comprised reading the case vignette, controlling the time, and taking notes. Regardless of individual responsibilities, everyone must engage in the discussion;

4. Activity: The designated student read the case vignette and the first question, opening a group discussion. Once the answer was defined, students were asked to flip the cardboard, accessing the answers. This immediate feedback guides the clinical management course and allows subsequent questions. Afterwards, the case vignette continues, with a new event and a new question. The dynamics are repeated until the end of the session, which includes three or four rounds. Up to this stage, the mediator has an observer's role and their intervention should be minimal. Each corner station lasts approximately 15 minutes.

5. Debriefing: After the end of the section, the instructor starts the discussion with all participants. Since students already had access to the correct answer during the activity, this moment is ideal for a more in-depth debate. At this point, many students bring up real cases they have seen in the clinic, or other possible approaches they have witnessed or learned about. This explanatory session is also an opportunity to present relevant graphics, figures, and diagrams. The discussion lasts 20 to 30 minutes.
Steps 3 to 5 are repeated until the end of all four stations. The total duration of the activity is between $2 \mathrm{~h} 30$ and $3 \mathrm{~h}$. A 20-minute break at mid-time is optional and to be defined according to the audience and the available time.

Figure 2. An example of students' positions in the classroom after the question presentation.

Case vignette 1

Case vignette 2

Case vignette 4

Case vignette 3

Table 1. Topics and subtopics selected for the activity.

\begin{tabular}{|c|c|}
\hline Main topic & Subtopic \\
\hline \multirow{3}{*}{ Acute febrile syndrome } & Differential diagnosis \\
\hline & Epidemiological considerations \\
\hline & Red flags \\
\hline \multirow{3}{*}{$\begin{array}{l}\text { Acute icterohemorrhagic } \\
\text { syndrome }\end{array}$} & Differential diagnosis \\
\hline & Investigation tools \\
\hline & $\begin{array}{l}\text { Management of the main } \\
\text { pathologies }\end{array}$ \\
\hline \multirow{2}{*}{ Sepsis } & New sepsis criteria \\
\hline & Management of sepsis case \\
\hline \multirow{3}{*}{$\begin{array}{l}\text { Lung infection in an } \\
\text { immunosuppressed } \\
\text { patient }\end{array}$} & Differential diagnosis \\
\hline & Investigation tools \\
\hline & $\begin{array}{l}\text { Management of the main } \\
\text { pathologies }\end{array}$ \\
\hline \multirow{3}{*}{$\begin{array}{l}\text { Focal lesion of the central } \\
\text { nervous system in a } \\
\text { patient living with HIV }\end{array}$} & Differential diagnosis \\
\hline & Investigation tools \\
\hline & $\begin{array}{l}\text { Management of the main } \\
\text { pathologies }\end{array}$ \\
\hline \multirow{3}{*}{$\begin{array}{l}\text { Meningoencephalitis in } \\
\text { an immunosuppressed } \\
\text { patient }\end{array}$} & Differential diagnosis \\
\hline & Investigation tools \\
\hline & $\begin{array}{l}\text { Management of the main } \\
\text { pathologies }\end{array}$ \\
\hline \multirow{2}{*}{$\begin{array}{l}\text { Immunizations for non- } \\
\text { pediatric populations }\end{array}$} & $\begin{array}{l}\text { Public health system vaccination } \\
\text { schedule for immunocompetent } \\
\text { adults }\end{array}$ \\
\hline & $\begin{array}{l}\text { Public health system vaccination } \\
\text { schedule for immunosuppressed } \\
\text { adults }\end{array}$ \\
\hline \multirow{4}{*}{$\begin{array}{l}\text { Sexually-transmitted } \\
\text { infections }\end{array}$} & Differential diagnosis \\
\hline & Investigation tools \\
\hline & $\begin{array}{l}\text { Management of the main } \\
\text { pathologies }\end{array}$ \\
\hline & $\begin{array}{l}\text { Indications for HIV post-exposure } \\
\text { prophylaxis }\end{array}$ \\
\hline
\end{tabular}




\section{DISCUSSION}

The teaching-learning process should encourage the students' interest, promoting the internal mobilization of theoretical contents, implementing behavioral changes and, finally, supporting the acquisition of a specific ability for practical application ${ }^{7}$. Despite its benefits, the implementation of active learning can be challenging; many instructors working in higher education are confident that they promote critical thinking and active teaching during their classes; however, the percentage of teachers who use active teaching strategies regularly can be as low as $9 \%{ }^{8}$.

A range of different active learning strategies for medical education has been described ${ }^{2}$. The current study describes our experience in implementing the Four Corners technique for the infectious disease medical course. The adapted format of the strategy showed to be best suited for open-ended questions and promoted debate and exchange of ideas among students, who acted simultaneously as students and instructors, and received immediate feedback from their peers.

This activity performed differently depending on the selected topic, with controversial issues being more prone to discussion. In our experience, the "Acute febrile syndrome" case vignette, describing a young patient with acute nonspecific symptoms associated with fever in the emergency department, admits many differential diagnoses. The topic proved to be an opportunity to emphasize the importance of the epidemiological context when defining the main hypotheses. As a more objective topic, the case vignette concerning immunizations in non-pediatric populations performed differently. We noticed the mutual help between students aiming to recall all the vaccines recommended for each case, without major controversies.

The indication of a preparatory material via online platform prior to the activity showed to be a useful strategy, as the students' former knowledge on a given topic enriches the discussion and increases the likelihood of class participation. Many traditional classes and lectures that are seemingly consolidated can be adapted for an active learning strategy like Four Corners, especially in situations where students already have some prior knowledge. Active approaches change the nature of the learning experience but do not always require a change in the given subject.

This study describes our in-field experience with an active learning strategy. Nevertheless, it has some limitations; it was performed in a single institution, and our strategy may not apply to other institutions or in different areas. The technique also requires previous knowledge on the topic, as well as the students' engagement and participation; therefore, it may not be adequate in the first years of the medical course.
Although the activity had a very good acceptance by the students and a positive evaluation at the end of the course, a direct comparison of students' performance before and after the strategy was not performed.

The medical literature has no articles addressing the objective performance of the Four Corners Strategy. For other active learning techniques, few studies demonstrated a higher performance compared to the traditional ones. The flipped classroom approach significantly improved student performance in the cumulative grades but made no difference for the practical exam scores ${ }^{9}$. The gamified training in medical education was evaluated by Clément et al., who demonstrated that the knowledge mean scores were significantly higher after the game than before and persisted at least three months later ${ }^{10}$. For the team-based learning (TBL), the authors concluded the activity was significantly associated with greater acceptance and higher motivation; otherwise, knowledge acquisition was similar between the TBL and the regular lectures ${ }^{11}$.

A successful experience using active online learning to teach medical content has been described. Although these novel methods pose challenges, a clear institutional approach and the availability of technical support for students and teachers are essential for the successful implementation of active learning strategies ${ }^{12}$.

\section{CONCLUSION}

"One must learn by doing a thing; for though you think you know it, you have no certainty until you try" - Sophocles, cited in 13

The medical education improvement necessarily involves understanding the teacher's role as a mediator of the learning process. Proposing new teaching strategies is challenging and requires frequent adjustments. Previous studies have demonstrated the benefits of active learning in medical education ${ }^{3}$. The Four Corners strategy improves the student's engagement with the learning process and increases their ability to interact with peers and extrapolate theoretical concepts into practical situations. It is an efficient strategy to include an extensive theoretical content into a relative short discussion time, and a potentially useful tool to engage students in online teaching modalities.

\section{AUTHORS' CONTRIBUTION}

Bárbara Labella Henriques: Substantial contributions to the study concept or design; or the acquisition, analysis, or interpretation of data for the study. Maria Claudia Stockler Almeida: Final approval of the version to be published. Ronaldo Cesar Borges Gryschek: Agreement to be accountable for 
all aspects of the study, ensuring that questions related to the integrity of the study are appropriately investigated and resolved. Vivian Avelino-Silva: Drafting the manuscript or revising it critically for important intellectual content.

\section{CONFLICTS OF INTEREST}

We declare no conflicts of interest.

\section{SOURCES OF FUNDING}

We declare no sources of funding.

\section{REFERENCES}

1. Graffam B. Medical Teacher Active learning in medical education: Strategies for beginning implementation. Med Teach. 2007;29(1):38-42.

2. Carlin RD. Survey results and a recommendation for a change in U.S. medical physiology curricula. Academic medicine : journal of the Association of American Medical Colleges. U.S. National Library of Medicine; 1989 [access in 19 may 2021]. Available from: https://www.ncbi. nlm.nih.gov/pubmed/2923648.

3. Rich SK, Keim RG, Shuler CF. Problem-based learning versus a traditional educational methodology: a comparison of preclinical and clinical periodontics performance. Journal of dental education. U.S. National Library of Medicine; 2005 [access in 19 may 2021]. Available from: https:// www.ncbi.nlm.nih.gov/pubmed/15947211.

4. da Silva LFF, Baracat EC, Auler JOC. Reestruturação Curricular na Faculdade de Medicina da USP: Integrando Conteúdos e Valorizando Competências. Revista de Graduação da USP. 2016;1(1):95-100 [access in 19 may 2021]. Available from: http://www.revistas.usp.br/gradmais/article/ view/117736\%0A.
5. Herrell AL, Jordan M. Fifty strategies for teaching English language learners. 3rd ed. Upper Saddle River, NJ: Pearson/Merrill Prentice Hall; 2008.

6. Lodico MG, Spaulding DT, Voegtle KH. Methods in educational research: from theory to practice. 1st ed. San Francisco, CA: Jossey-Bass; 2010.

7. Tempski PZ, Martins MA. Modelos teóricos do processo ensinoAprendizagem aplicado às estratégias educacionais de simulação. In: Augusto Scalabrini Neto, Carolina Felipe Soares Brandão, editors. Simulação Realística e Treinamento de Habilidades. São Paulo: Editora Atheneu; 2017. p. 253.

8. Paul RW, Elder L, Bartell T. California Teacher Preparation for Instruction in Critical Thinking: Research Findings and Policy Recommendations. Sacramento (CA): California Commission on Teacher Credentialing; 1997 Mar. ERIC Number: ED437379.

9. Bhai SA, li O, Poustinchian B, Bhai SA. The flipped classroom: a novel approach to physical examination skills for osteopathic medical students. J Osteopat Med. 2021;121(5):475-81 doi: 10.1515/jom-2020-0198.

10. Clément A, Delage R, Chollier M, Josse L, Gaudry S, Zahar J-R, et al. Prospective study on a fast-track training in psychiatry for medical students: the psychiatric hat game. BMC Med Educ. 2020;20(373):1-7 doi: 10.1186/s12909-020-02304-0.

11. Rezende AB, de Oliveira AGF, Vale TC, Teixeira LAS, Lima ARA, Lucchetti $A L G$, et al. Comparison of Team-Based Learning versus Traditional Lectures in Neuroanatomy: Medical Student Knowledge and Satisfaction. Anat Sci Educ. 2020;13(5):591-601.

12. O'doherty D, Dromey M, Lougheed J, Hannigan A, Last J, Mcgrath D. Barriers and solutions to online learning in medical education-an integrative review. BMC Med Educ. 2018;18(130):1-11.

13. Bonwell CC, Eison JA. Active learning: creating excitement in the classroom. 1st ed. Washington, DC: George Washington University, ERIC Clearinghouse on Higher Education; 1991. 